\title{
Strategizing Hospitality Internship for Effective Implementation: Perspectives of Internship Coordinators
}

\section{Muhammad Nazreen Ezyan Soffi, Siti Fatimah Mohamad}

To Link this Article: http://dx.doi.org/10.6007/IJARBSS/v11-i4/9843

DOI:10.6007/IJARBSS/v11-i4/9843

Received: 24 February 2021, Revised: 26 March 2021, Accepted: 16 April 2021

Published Online: 30 April 2021

In-Text Citation: (Soffi \& Mohamad, 2021)

To Cite this Article: Soffi, M. N. E., \& Mohamad, S. F. (2021). Strategizing Hospitality Internship for Effective Implementation: Perspectives of Internship Coordinators. International Journal of Academic Research in Business and Social Sciences, 11(4), 1469-1480.

\section{Copyright: @ 2021 The Author(s)}

Published by Human Resource Management Academic Research Society (www.hrmars.com) This article is published under the Creative Commons Attribution (CC BY 4.0) license. Anyone may reproduce, distribute, translate and create derivative works of this article (for both commercial and non-commercial purposes), subject to full attribution to the original publication and authors. The full terms of this license may be seen at: http://creativecommons.org/licences/by/4.0/legalcode

Vol. 11, No. 4, 2021, Pg. 1469 - 1480

Full Terms \& Conditions of access and use can be found at http://hrmars.com/index.php/pages/detail/publication-ethics 


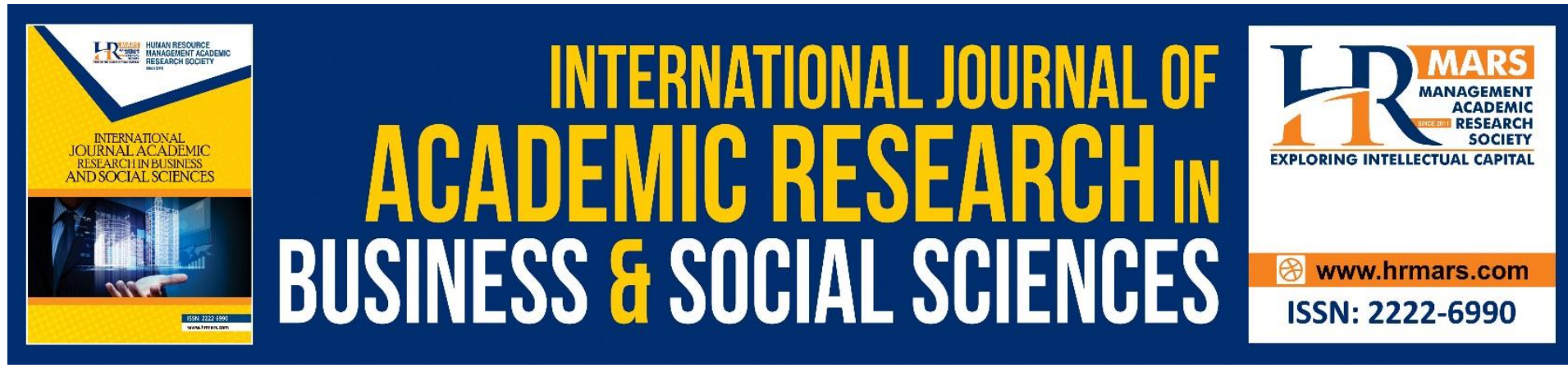

\title{
Strategizing Hospitality Internship for Effective Implementation: Perspectives of Internship Coordinators
}

\author{
Muhammad Nazreen Ezyan Soffi ${ }^{1}$, Siti Fatimah Mohamad ${ }^{2}$ \\ ${ }^{1}$ Department of Food Service and Management, Faculty of Food Science and Technology, \\ Universiti Putra Malaysia, 43400 Serdang, Selangor, Malaysia, ${ }^{2}$ Department of Food Service \\ and Management, Faculty of Food Science and Technology, Universiti Putra Malaysia, 43400 \\ Serdang, Selangor, Malaysia \\ Email: muhd.ezyan@gmail.com,s_fatimah@upm.edu.my
}

\begin{abstract}
An internship is an experiential learning process where undergraduates have to undergo practical training in a chosen organization. The primary purpose of an internship is to allow the undergraduates to apply knowledge and skills they have learned in classrooms, thus achieving thorough learning of the subject matter. However, there are challenges in an internship, not only to interns but also to coordinators who plan and manage the internship implementation. The internship challenges have been well-studied, but the strategies to overcome the challenges should be planned according to the internship context, such as the program study and region. Hence, this paper aimed to identify strategies applied by universities in escalating undergraduates' competencies through an effective hospitality internship program. This study employed a qualitative approach by conducting semistructured interviews with the internship coordinators who had experiences in handling hospitality internship in Malaysian public universities. The instrument was developed based on the literature review and discussion with the experts. There were seven internship coordinators interviewed in this study, and the findings were analyzed using thematic analysis with the help of ATLAS.ti 8 software. This study proposed five strategies used in the public universities to escalate the effectiveness of the hospitality internship implementation: i) communication, ii) revision, iii) networking, iv) blocklist and v) guidance. The findings are expected to add value not only to the current literature within the hospitality field but also to all the stakeholders of the internship program, particularly in Malaysian public universities, to structuring a successful and effective internship program.
\end{abstract}

Keywords: Hospitality Internship, Internship Strategies, Internship Coordinator, Public Universities, Effective Internship

\section{Introduction}

An internship is a job training that covers many professional field or job and usually taken up by college and university students as a mandatory requirement during their studies (Hoyle \& 
Goffnett, 2013; Mohammed \& Rashid, 2016; Renganathan, Abdul Karim \& Chong, 2012). An internship has been made as a compulsory requirement for students at all levels of higher education, particularly in Malaysia. The primary purpose of the internship program is to give exposure to students about the real world of work (Mohammed \& Rashid, 2016). It is a platform that offers various opportunities to interns by providing learning experiences in their chosen area of work, building industrial network and skills (Chiu, Mahat, Rashid, Razak \& Omar, 2016). An internship has been set as a primary component in most of the hospitality and tourism management curriculums (Maertz, Stoeberl \& Marks, 2014). In Malaysia, the hospitality and tourism industry is expected to offer 600,000 new job opportunities which indicate there was a need for many more skilled and work-ready graduates in the coming decades (Hussain, Ahmad, Ragavan \& Leong, 2020). Thus, implementing a successful internship program is vital to ensure that students are well-equipped with the necessary knowledge, skills, and abilities for their employment.

Over the years, there were challenges experienced by the stakeholders of the internship: students, university and employers, which affect the process of delivering meaningful internship experiences to students (Hoyle \& Goffnett, 2013). The most common factors that create dissatisfaction and decreased motivation among interns including low pay, poor employee-supervisor relations, poor communication, disorganized work environment, long working hours and a hectic working environment, particularly in the hospitality industry (Collins, 2002; Lam \& Ching, 2007). Despite an internship is perceived to help students with employable skills such as teamwork, technical, and vocational; students have been reported were not well-equipped with those respective skills. Hence, it can be concluded that the internship failed to serve as a platform to adequately trained the students (Kenayathulla, Ahmad \& Idris, 2019). Besides, there was also a weak connection between higher education institutions and industries, mainly for the hospitality programs (Fournier \& Ineson, 2010; Yiu \& Law, 2012). As such, it would be difficult for students to find reputable organizations that offer a worthy internship program and experience.

It is essential to improve internship programs to ensure a continuous flow of new talents to fill in job positions in the labour market. Studies have indicated that interns who gained unpleasant internship experiences in the hospitality industry might cause the students to become uncertain of their career and probably leave the hospitality industry (Fidgeon, 2010; Raybould \& Wilkins, 2005; Roy \& Skyes, 2017). It is also supported by Teng (2008), who reported that the hospitality graduates had unfavourable attitudes toward working and making careers in the hospitality industry after completing their internship. Singh and Dutta (2010) affirmed that there was a difference between interns' expectations and their actual experiences, where internship experiences are commonly derived from practical work instructions and supervisors' support.

Apart from the above issues, the role of an internship coordinator is one of the significant factors that predict the success or failure of an internship program. Coordinators with heavy workloads or lack of industry knowledge may lead to inadequate emphasis and planning of the internship program, which later affects the internship experiences gain by interns (Beggs, Ross \& Goodwin, 2008; McMahon \& Quinn, 1995). Undoubtedly, a careful plan and strategy involving all internship stakeholders in constructing an internship program can maximize interns true potential and later produce well-rounded graduates (Manickam \& Chin, 2015). Therefore, the objective of this paper was to discover strategies applied by public universities 
to achieve an effective hospitality internship program, from the perspectives of internship coordinators

\section{Literature Review}

Maertz, Stoeberl and Marks (2014) discussed that a successful internship could benefit multiple stakeholders; students could learn job-related knowledge and skills to prepare for their workplace transition, universities could achieve a higher corporate and community visibility, and employers could have competent talent pool. The authors also proposed that one way for a university to maximize the benefits of an internship is by designing an internship program that meets the need of both interns and employers. It is essential to foster a university-employer relationship that will increase the potential for continuous internship placements and job offers to graduates. Universities must ensure that their databases, including work contents, faculty and employer evaluations, employment offer, and employers' contact information, are precise and updated.

Students with insufficient industry exposure might be surprised with operations and workplace settings during their internship (Zhang \& Wu, 2004). Therefore, there is a need for the university to provide initial exposures to students in regards to the industry before they go for an internship program. Lin and Anantharajah (2019) suggested that universities should build linkages with the industry where interaction between industry representatives and students are made through roadshows, talks and seminars. This process will help to manage students' expectations toward the labour market and industry, and to avoid them from being disappointed and demotivated throughout their internship program. At the same time, it could help employers to understand what students are looking for in their internship experience and employment as a whole. For instance, a study by Brown, Arendt and Bosselman (2014) reported that graduates perceived that enjoyable and challenging careers are vital to them. This information can guide employers to create a working environment that suits to the employees' preference. Thus, industrial exposure and communication among university, students and employers are essential in designing an impactful internship program.

Another critical factor in ensuring the success of an internship program is realizing the learning objectives of an internship. Burdett and Barker (2017) reported that faculty coordinators and mentors found that one of the main factors contributing to a successful internship is the quality, planning and work relevance when dealing with employers. Learning for both students and organizations are more likely to occur when they work on projects that are closely related to the students' program, as the students can apply the knowledge they obtained from class to the industry. It can be concluded that internship goals and expectations must be communicated clearly to the industry in order to produce graduates with competencies, where the competencies should be relevant to students' specialization and their future careers. Besides, systematic record-keeping and database management by internship coordinators play significant roles in the success of an internship program.

\section{Methodology}

This paper adopted a qualitative research design using semi-structured interviews where the questions were developed from the literature review and discussion with the experts. Purposive sampling was employed to gather participants where they fit into these criteria; 1 ) 
internship coordinators who are in charge for planning and coordinating an internship program, and 2) internship coordinators from the public universities that offer a bachelor degree program in food service or hospitality. This study obtained ethical research approval, which was granted by the Ethics Committee for Research Involving Human Subjects from the researcher's institution. The ethical approval ensured that this study followed ethical principles throughout the data collection, including voluntary participation, the anonymity and confidentiality of responses. Seven participants from public universities across Malaysia agreed to participate in the study. The interviews were conducted face-to-face, while telephone calls were made if the participant's location was miles away from the researcher. The interviews were audio-recorded and later transcribed. The transcripts were analyzed using thematic analysis to identify a pattern or theme to achieve the study objective. The reliability and validity of the findings were ensured through inter-rater agreement and expert review.

\section{Findings}

\section{Demographic Information}

The study managed to approach nine internship coordinators to ascertain their willingness to participate in the study but only seven were agreed to participate. Details of the respondents are shown in Table 1.

Table 1: Demographic Characteristics of Internship Coordinators

\begin{tabular}{|c|c|c|c|}
\hline $\begin{array}{l}\text { Respondent } \\
\text { Code }\end{array}$ & $\begin{array}{l}\text { University } \\
\text { Code }\end{array}$ & Program Field & $\begin{array}{l}\text { Location } \\
\text { (in Malaysia) }\end{array}$ \\
\hline R1 & $\begin{array}{l}\text { University } \\
\text { A }\end{array}$ & Hospitality & Eastern region \\
\hline R2 & $\begin{array}{l}\text { University } \\
\mathrm{B}\end{array}$ & Food Service Management & Central region \\
\hline R3 & $\begin{array}{l}\text { University } \\
\text { C }\end{array}$ & $\begin{array}{l}\text { Tourism Planning and Hospitality } \\
\text { Management }\end{array}$ & Southern region \\
\hline R4 & $\begin{array}{l}\text { University } \\
\text { D }\end{array}$ & Business (Hotel Management) & East Malaysia \\
\hline R5 & $\begin{array}{l}\text { University } \\
\mathrm{E}\end{array}$ & Food Service Management & Central region \\
\hline R6 & $\begin{array}{l}\text { University } \\
\mathrm{E}\end{array}$ & Hotel Management & Central region \\
\hline R7 & $\begin{array}{l}\text { University } \\
\mathrm{F}\end{array}$ & Hospitality Management & Northern region \\
\hline
\end{tabular}

Strategies Used to Increase the Effectiveness of the Hospitality Internship Program Based on the interviews with the internship coordinators from six different public universities, there were five types of strategies used to enhance the effectiveness of the internship program: i) communication, ii) revision, iii) networking, iv) blocklist and v) guidance. Elaboration and examples of each strategy are described as follows: 


\section{i) Communication}

One of the respondents stated that a strategy they used in solving the problem of unutilized interns was to encourage the company in giving feedback to the internship coordinator through discussion. Employers can convey the issue during the internship visit by a lecturer in charge or can directly contact the internship coordinator.

"We encouraged the supervisor to give feedback about our students during the internship visit. If the supervisor felt the student is not fully utilized, they can convey the feedback to the top management and to us to discuss how the student can be better utilized in the future." (R3)

Apart from the issue experienced by the employer, interns also faced problems during their internship. Hence, the internship coordinators created a communication platform, commonly through WhatsApp to share and discuss the problems that interns experienced at their workplace with the internship coordinators. Interns may discuss openly with the coordinators on any problems, but if there were serious issues faced by the interns or contradict with the employer's response, the coordinators would require evidence and discuss privately.

"Students can communicate with me if they have any problem. However, the student must bring evidence if the company reported that student did not do anything and then we will have a long discussion to discuss this matter." (R3)

"We created WhatsApp group for every batch who go for internship. Every batch has a WhatsApp group that include all interns and me, as the internship coordinator. If the students have any problem, they can convey the issue in the WhatsApp group." (R5)

\section{ii) Revision}

Some companies raised their concerns regarding a short period of the internship program. Most of the internship programs range from four to six months. Some respondents mentioned that the strategies used to overcome this problem is by doing revision and adjustment to the internship program. The four-month programs were extended to sixmonth. A study by Mihail (2006) suggested that the ideal internship duration ranged from six to 12 months, as it would benefit both students and employers. Students could further develop their skills and employers might have sufficient time to assess them as potential employees. The statements below reflected the strategies applied by a university in the central region of Malaysia to revise and adjust its internship program:

"Our internship duration is only for four months. Currently, we are revising our degree curriculum program. We will change from 8 credit hour to 12 credit hour and make the internship duration to six months. Now it is in the process of reviewing and obtaining the approval. Probably next intake will go for the six months internship program." (R5)

"According to the curriculum procedures, the students cannot do an internship during their semester break. Currently, the first internship is six weeks, and then after the semester break, students will go for another six weeks internship. Finally, they have to do their 16 weeks internship. The reason why we divide into three internship periods is to allow students to have experience in understanding and adapting to the hotel industry. So we revise and make the sixth semester as the internship placement for the students, and it will be a six-month program, which equivalent to 24 weeks." (R6) 
Another public university revised its internship program by transforming a general curriculum program to a specific program. A respondent from the East Malaysia university shared their dilemma where the students do not have an interest in pursuing a career in the hospitality industry. The students perceived they are business students who should not be placed in the hospitality industry for their internship.

"We review our curriculum program to tackle the problem that our students think they are business students and lack of interest in the hotel industry. Besides, the internship duration is only three months. We are in the process of changing the curriculum program. Currently, the name of our degree is Bachelor of Business, with specialization in the hotel management. We want to change the name to Bachelor in Hospitality. We want our program to be a pure hotel degree rather than a business degree." (R4)

\section{Networking}

Some of the undergraduate students had difficulties in searching for an internship place. The respondent of this study shared her university's strategy by using a database software that includes all recommended companies for an internship placement. This data was shared and can be accessed by the university's branches that are scattered all across Malaysia. This strategy would ease the process of searching and selecting an internship placement.

"Let say if students did not get any place for the internship, we will contact our colleague from another branch or refer to the recommended list of internship companies from the database provided by our university. Then our students will approach the proposed company and apply for their internship." (R5)

Other than using a database, making a direct connection with industries is another feasible strategy mentioned by the respondent of this study. A person who connects with the industry may not be an internship coordinator. Any lecturers who have a good relationship with the industry related to their field may provide information to help the coordinator for the internship planning.

"We have a network with a Singapore hotel. We have a person in charge who manages industrial networking. This person will update and give information on the dates that the Singapore hotel requires for interns and what are the needed requirements. Normally, the person in charge will give the information to the internship coordinator through email." (R7)

\section{Blocklist}

Blocklisting was the most applied strategy suggested by most of the respondents from this study, in order to improve the effectiveness of the internship program. The coordinator would blocklist the companies that consistently created difficulties during the process of the internship, including companies that breach promises and agreement, misuse interns or not responding to the coordinator's request or question.

"We blocklist many companies as they rejected students without proper justification, had mismatch skill issues and not fulfilling their promises for the internship program." (R1) 
"We blocklist the companies where their staff had discipline problems and not showing good examples to our students, some of them take advantages of our students. There were issues where a company staff misused our students and did not train them, so we blocklist the company." (R2)

"Normally, based on the previous experience and evidence, we are aware of the companies with problems. We have to blocklist the company, and we will not send our students there for an internship program." (R5)

\section{Guidance}

The internship process as a whole can be rigorous and unpredictable, apart from the uncooperative companies that create frustration for both the internship coordinators and students. Guidance is one of the strategies to overcome this issue where the internship coordinators have to play a crucial role in giving advice and exposure to students. The internship program is bound to the timeline, where the coordinators and students should comply with the deadlines given by their university. Some students would be merely waiting for the company's reply to confirm the internship placement, as they are afraid to follow up several times which may lead to rejection. Hence, the internship coordinator would advise going to other companies to avoid delay. The students were taught to be professional when liaising with companies. Though the issue of not responding in time is perceived as a minor concern to a company, it will result in the late completion of the students' internship program and later affect their graduation.

"If the company does not give feedback or too late in giving feedback, I would advise the student to search for another company. Do not wait for the company that is too long in giving a response. If a company does not respond within the given deadline, the student has to search for another company. There are many companies in Malaysia, and do not simply focus on one particular company." (R1)

An internship program serves as a platform to prepare students for their employment, where interns are expected to prepare themselves to be professional in performing their job. The internship coordinators played a role in advising students on how to demonstrate professionalism at work. The students have to maintain their professionalism though they are having a personal relationship at work.

"There are students who fall in love at the workplace during the internship, and it is hard for us to prevent that from happening. As the internship coordinator, I advise the students to behave and take care of themselves. Sometimes, having a relationship at a workplace disturb the internship process; some would not affect the interns' performance. We can only advise the students, but it depends on how they react to our advice, as different students have different attitudes. Normally, we advise during the internship briefing on what they are going to expect, the dos and don'ts. If we obtain a report that our students have affairs at the workplace, we will advise them face to face." (R7)

Besides guiding the students on professionalism, the internship coordinators also gave exposure to the students about the real world of the industry. The students should have a realistic expectation once they join the industry, where this will avoid dissatisfaction during 
their internship and real work. There were several ways taken by the coordinators in opening the students' view toward the industry, including organizing an industrial visit and having a session with the seniors.

"We tell the students about the real world of working life, and as a student, you cannot expect that things will be beautiful and easy. When you go for an internship, not everything will match with your expectation." (R3)

"Our students are so choosy about their internship place due to the hotels in this region are not providing accommodation. I talk to my student, you can search for a hotel near to your hometown if it is 4- to 5-star hotel. You have to look for the hotel by yourself. If the student failed to find a suitable hotel, I will contact my friends from the industry and place the student there. If the student is not satisfied as there is no accommodation offered by the hotel, then I will direct the student to go to Hotel XX as this hotel is known to provide accommodation to interns." (R4)

"We do field trips or industrial visit with our students to give exposure to them. Besides, we also conduct a sharing session between the first semester students and their senior to share experiences on the internship." (R6)

The overall strategies taken by the internship coordinators in improving the quality of the hospitality internship program is shown in Figure 1.

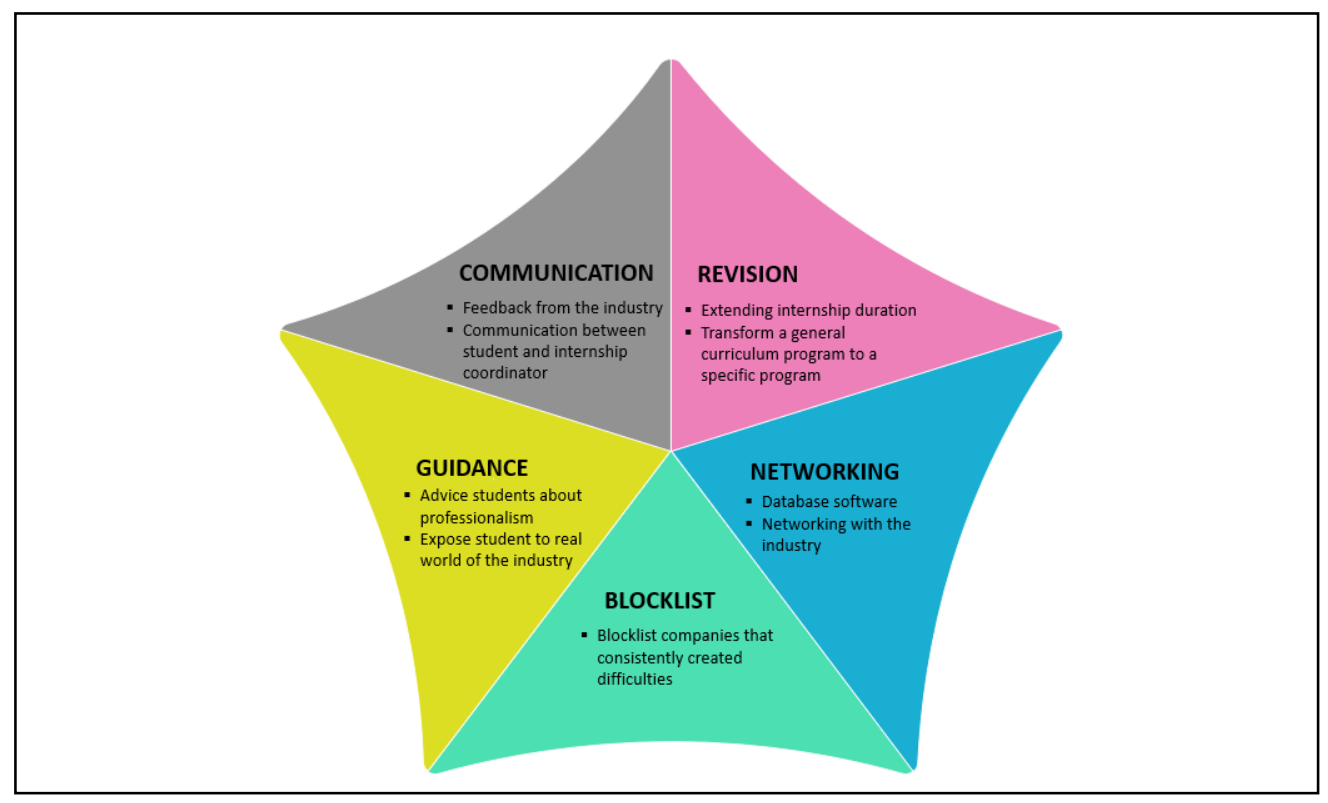

Figure 1: Five strategies applied by the internship coordinator in improving the hospitality internship program in Malaysian public universities

\section{Discussions}

The results of this study presented five strategies applied by the internship coordinators from the Malaysian public universities, within the context of the hospitality program. The five strategies were communication, revision, networking, blocklist and guidance. The findings of this study is anticipated to extend the literature review in the field of internship studies, 
particularly within the hospitality area. Practically, this study is also expected to contribute ideas to the related internship stakeholders (university, student and employer) on the components in the internship process that should be strategized and improved. For example, although the students are given freedom in choosing their internship place, they should be guided by the internship coordinator to ensure that the students will obtain a meaningful experience throughout their internship. Later, it will help to escalate their skills and prepare them for employment once they graduated. The findings of this study may also shed some lights to both students and employers. Although the strategies revealed in this study were perceived and applied by the internship coordinators, students and employers may play their roles in facilitating the internship process. The co-operation among all the stakeholders is essential to realizing an effective internship program. (Hoyle \& Goffnett, 2013; Ishengoma \& Vaaland, 2016).

There were some limitations of this study, comprising time constraint and the disadvantage of a telephone interview. Due to the time constraint of the research duration, this study was unable to triangulate its findings with the perspectives from the top management of the faculty and university. It is well-understood that an internship coordinator is a person in charge who plan and manage an internship program at a university. However, the coordinators are bound with the policies and procedures instructed by their university. Thus, views from the university's top management may help to understand better the situations that limit the effectiveness of an internship program. Another limitation was the telephone interview that was conducted to the respondents who was afar from the researcher. As compared to face-to-face interviews, telephone interview was doubted in providing rich data for a qualitative study. As the duration of a telephone interview is commonly short, it reduces the in-depth discussion (Novick, 2008).

It is recommended that future research conduct a study with a similar topic from the perspective of private universities. The nature of a private university is different from a public university, in term of economic, environmental and social (Othman \& Othman, 2014). This study can also be extended by investigating the perspectives of other stakeholders: employers and students. It is hoped by triangulating data from all the stakeholders will provide intense data which later contribute to profound insights in improving the quality of internship programs in Malaysia.

\section{Acknowledgements}

This research was financially supported by the Universiti Putra Malaysia under the project of GP-IPM 9620300

\section{References}

Brown, E. A., Arendt, S. W., \& Bosselman, R. H. (2014). Hospitality management graduates' perceptions of career factor importance and career factor experience. International Journal of Hospitality Management, 37, 58-67.

Burdett, J. \& Barker, S. (2017). University students in the workplace strategies for successful industry placement experiences. Development and Learning in Organizations, 31(1), 1518. 
Chiu, L. K., Mahat, N. I., Rashid, B., Razak, N. A., \& Omar, H. (2016). Assessing students' knowledge and soft skills competency in the industrial training programme: The employers' perspective. Review of European Studies, 8(1), 123-133.

Collins, A. B. (2002). Gateway to the real world, industrial training: Dilemmas and problems. Tourism management, 23(1), 93-96.

Fidgeon, P. R. (2010). Tourism education and curriculum design: A time for consolidation and review? Tourism Management, 31, 699-723.

Fournier, H., \& Ineson, E. M. (2010). Closing the gap between education and industry: skills' and competencies' requirements for food service internships in Switzerland. Journal of Hospitality \& Tourism Education, 22(4), 33-42.

Hoyle, J., \& Goffnett, S. (2013). A stakeholder framework for designing and directing effective marketing internships. Journal for Advancement of Marketing Education, 21(1), 1-15.

Hussain, K., Ahmad, A.M., Ragavan, N.A., \& Leong, Q.L. (2020). Raising standards for hospitality and tourism education in Malaysia. Worldwide Hospitality and Tourism Themes, 12(2), 199-206.

Ishengoma, E., \& Vaaland, T.I. (2016). Can university-industry linkages stimulate student employability?. Education + Training, 58(1), 18-44.

Kenayathulla, H.B., Ahmad, N.A., \& Idris, A.R. (2019). Gaps between competence and importance of employability skills: evidence from Malaysia. Higher Education Evaluation and Development, 13(2), 97-112.

Lam, T., \& Ching, L. (2007). An exploratory study of an internship program: The case of Hong Kong students. Hospitality Management, 26, 336-351.

Lin, C. Y., \& Anantharajah, S. (2019). Perceived expectations of internships: Case study of a private university in Malaysia. Asia-Pacific Journal of Innovation in Hospitality and Tourism 8(1), 1-16.

Maertz, C. P., Stoeberl, P. A., \& Marks, J. (2014). Building successful internships: Lessons from the research for interns, schools, and employers. Career Development International, 19(1), 123-142.

McMahon, U., \& Quinn, U. (1995). Maximizing the hospitality management student work placement experience: A case study. Education + Training, 37(4), 13-17.

Mihail, D. M., (2006). Internship at Greek Universities: An exploratory study. Journal of Workplace Learning, 18, 28-41.

Mohammed, A. A., \& Rashid, B. (2016). The moderating influence of internship program on the relationship between undergraduates' perception and their intention to join tourism and hospitality industry: A theoretical model. International Review of Management and Marketing, 6(2), 317-321.

Novick G. (2008). Is there a bias against telephone interviews in qualitative research? Research in Nursing \& Health, 31(4), 391-398.

Othman, R., \& Othman, R. (2014). Higher education institutions and social performance: Evidence from public and private universities. International Journal of Business \& Society, 15(1), 1-18.

Raybould, M., \& Wilkins, H. (2005). Over-qualified and under-experienced. International Journal of Contemporary Hospitality Management, 17(3), 203-215.

Renganathan, S., Abdul Karim, Z. A., \& Chong, S. (2012). Students' perception of industrial internship programme. Education + Training, 54(2/3), 180-191. 
Roy, J., \& Sykes, D. (2017). A review of internship opportunities in online learning: Building a new conceptual framework for a self-regulated internship in hospitality. International Journal of e-Learning and Distance Education, 32(1), 1-17.

Singh, A., \& Dutta, K. (2010). Hospitality internship placements: Analysis for United Kingdom and India. Journal of Services Research, 10(1), 85-99.

Teng, C. C. (2008). The effects of personality traits and attitudes on student uptake in hospitality employment. International Journal of Hospitality Management, 27(1), 7686.

Yiu, M., \& Law, R. (2012). A review of hospitality internship: Different perspectives of students, employers, and educators. Journal of teaching in Travel \& Tourism, 12(4), 377402.

Zhang, H. Q., \& Wu, E. (2004). Human resources issues facing the hotel and travel industry in China. International Journal of Contemporary Hospitality Management, 16 (7), 424-428. 